\title{
SOME TECHNIQUES IN TEACHING WOMEN'S HISTORY
}

\author{
Sylvia D. Hoffert \\ Western Michigan University
}

Because women's history is a relatively new specialty within our discipline and many who teach it are self-taught, it seems that we have the opportunity to be less restricted by the attitudes and techniques that often dominate older specialties such as political or diplomatic history. We are free to try new techniques or modify old ones in an attempt to find those which are most effective in studying and analyzing women's roles within various cultures and societies. I would like to share the various techniques that I have used in my undergraduate survey course called "Women in the Western World."

One of the first things a women's history instructor has to decide when facing the problem of designing a course is what kind of orientation he or she wants. Here consciously or unconsciously, it becomes necessary to decide whether to approach the discipline through biography or social history. The biographical approach is more traditional and has 1 ts advantages. When women have been mentioned at all in elementary and high school history classes it has usually been in this way: "And now we' 11 read a biography of Florence. Nightingale. Wasn't she wonderful--brave, kind, self-sacrificing, and nurturing? She gave up marriage and a family to carry on a struggle to care for the sick and dying." Unfortunately many biographers or teachers do not consider the significance of such questions as why she had to settle for being a nurse rather than a doctor, why she had to struggle with a maledominated government bureaucracy, how her social class contributed to her success, and why she was able to carry out her reforms only by working through powerful men. But biographies are easy to find and usually concern women of the upper class who had enough leisure time to do things men considered historically significant.

A more recent technique is to teach women's history as social history. This is the method chosen for "Women of the Western World." Instead of concentrating on the lives of individual women, this approach emphasizes material relating to the status and roles of women in various periods of western society.

Once the choice has been made there are a number of other things to be taken into consideration. First of all it quickly became apparent that the students who registered for my class had little or no background in the area. This was demonstrated when, during the first week of class, they were given a list of eighty-five famous and infamous women to identify. A "good" score on the quiz was 15. Many of them knew something about Catherine the Great and Elizabeth Cady Stanton but few of them had ever heard of Elizabeth Blackwel1 or Emmeline Pankhurst.

The students' lack of background was perhaps less troubling than their lack of sensitivity towards the inferior status granted women within Western society. Perhaps this is to be expected in a discipline that has been traditionally dominated by male historians who have had the opportunity and privilege of choosing whom to include and whom to leave out of the chronicle of history. They have tended to view accomplishment worthy of comment from a public perspective. Thus it is not surprising that students are introduced to great soldiers, statesmen, frontiersmen, and entrepreneurs. But the accomplishments of most women have been more private. Women may have had religious influence or tamed the American wilderness, but many did it privately by being good wives and mothers. Men may value their contribution but will rarely discuss the historical significance of domesticity and successful child rearing. They also find it easy to ignore the economic contributions of women 
on the farms and in the factories. Thus only a few women grace the pages of history texts from grade school on up.

So in the introductory part of my course some time is spent in an attempt to make the students more sensitive to women's position in society and the implications of that position, in part by discussion of what roles and socialization are and why they are important to society. Because the learning process must include emotional as well as intellectual involvement, the technique of role-playing is used to encourage the students to place themselves in the position of various kinds of women and think about as well as verbalize what those women were thinking and feeling. As they act out their roles they must, for example, consider how they would feel as a young mother on the American frontier. What problems would they have to face and how would they deal with them? What would they worry about? In acting out these feelings, students can come to some understanding about the kinds of social demands placed on both men and women. Students are asked to read Betty Friedan's The Feminine Mystique ${ }^{1}$ and Ellen Peck's The Baby Trap $^{2}$ in order to discuss the issue of questioning social roles and the importance of finding personal fulfillment in 1ife. An essay titled "Curtain Raiser"3 introduces the conflicting demands that society makes on people and how we as individuals can try to resolve these conflicts. These techniques have proven to be effective ways to heighten students' sensitivity to women's problems as well as help them to come to some conclusions regarding the choices they will have to make in their own lives.

I have used two methods to describe women's roles in Western society from Sparta through the twentieth century. The first and most traditional technique was the lecture-discussion-exam method. My experfence was that students seemed to have little difficulty remembering the factual material and various interpretations that had been discussed and as a group did well on the exams. Because testing in the traditional way only confirmed that my students were learning the material with little apparent difficulty, I decided to forgo the lecture-exam technique and experiment with the journal (notebook) comprised of their lecture and discussion notes, reading assignment notes, comments, and reflections. Comments were to be a sentence or two commenting on some aspect of the lectures, class discussion, or reading. Reflections were to be short essays in which the students were to develop and expand their ideas concerning some aspect of the class or reading material. Besides the regular reading assignments, students were assigned to do one book review and two scholarly article reviews. The journals are much more interesting to read than exams. But they also indicate whether or not a student really thinks about the material presented in class and in the reading. It is perhaps more difficult to grade journals than exams, but my final range of grades did not look much different than when exams were used.

The rapid proliferation of books in the area of women's history has made it easier to find adequate texts in some areas. There are at present, however, only a few books attempting to survey women in European life. I have used Emily James Putnam's The Lady, ${ }^{4}$ Susan G. Bell's Women: From the Greeks to the French Revolution, ${ }^{5}$ and Julia $0^{\prime}$ Faolain and Lauro Martines Not in God's Image: Women in History From the Greeks to the Victorians, 6 but have been dissatisfied with all of them. Although pleasant to read, Putnam's book lacks depth and analysis. The other two books are essentially books of readings, mostly original sources, which failed to either emotionally or intellectually involve my students. Therefore, recently I have not assigned readings in European History, and the students have had to rely on lectures. This is not necessarily the best solution, but until a more satisfactory text becomes available, this practice will probably continue. 
There are a number of good surveys on American women, including one which has come under attack recent1y, Page Smith's Daughters of the Promised Land. 7 Ruth Rosen, in her article "Sexism in History, or Writing Women's History Is a Tricky Business," maintains that Smith is guilty of ignorance, sexism, and psuedo-biological determinism and proceeds to point out examples of these abuses found in his book. 8 When $I$ assign the book, students are advised to read it "critically." Since their background is limited and most of them have been well socialized as students to accept the teacher's choice of a book as "good," I assume that many of them will not or cannot do what I have asked. So when they finish the book, they are asked to read Rosen's article. It is only after they have done so that many of them realize what was meant by "critical" reading. I could have told them what to look for in the beginning, but this way they see for themselves; and they learn more from that kind of experience.

In the past term papers have been assigned. The feasibility of such an assignment depends on the adequacy of the library. Since ours at one point had a dearth of material on women, I tried assigning term papers combining an analysis of novels and historical studies. Students were asked to relate the role of women in fiction to the reality of the lives of women during the period of the story. For example, the character of Scarlett o'Hara in Gone With the Wind could be discussed in terms of Anne F. Scott's The Southern

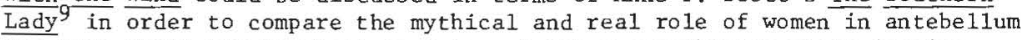
and post-Civil War Southern society. Another possibility might involve reading Duncan Crow's The Victorian Woman ${ }^{10}$ and $R$. F. Delderfie1d's God Is an Englishman ${ }^{11}$ or even Louisa May Alcott's Little Women in order to analyze the socialization of Victorian women.

Any of the techniques that have been described can be modified or expanded to meet the needs and goals of any history course, but I have found that they work particularly well in teaching women's history. Through them my students have been able to internalize material that in other courses they may simply have memorized in order to get a good grade.

\section{NOTES}

${ }^{1}$ (New York, 1963).

2 (New York, 1971).

${ }^{3}$ Carl Rogers and Barry Stevens, Person to Person: The Problem of Being Human (Walnut Creek, Cal., 1967), 9-11.

4 (Chicago, 1970).

5. (Be1mont, Ca1., 1973).

${ }^{6}$ (New York, 1973).

7 (Boston, 1970).

8 Journal of Marriage and the Family, XXXIII (August, 1971), 541-544.

${ }^{9}$ (Chicago, 1970).

${ }^{10}$ (New York, 1972).

11 (New York, 1970). 